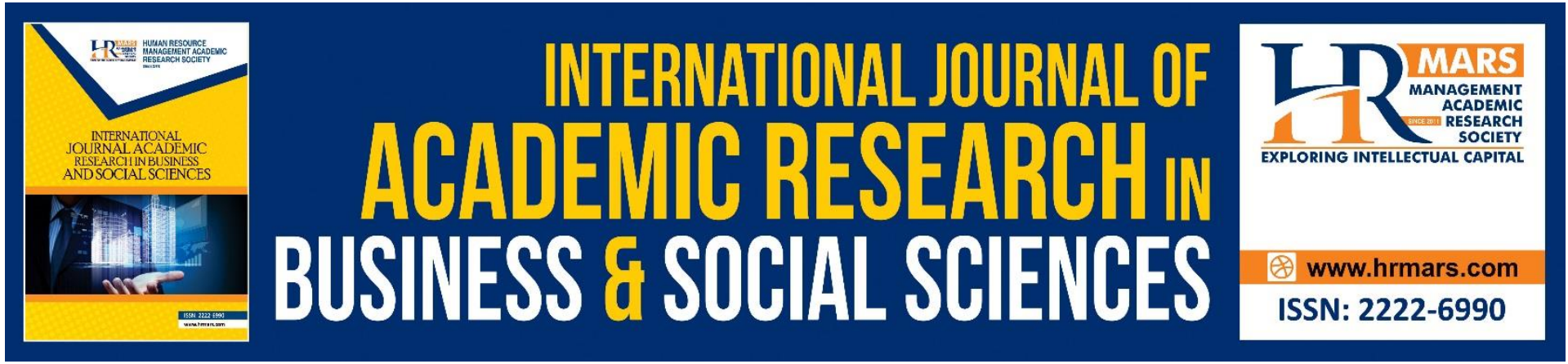

\title{
The Voices of Malay and Chinese University Students in Klang Valley Towards National Identity Formation in Malaysia
}

Siaw Bing, Lee Yok Fee, Ku Hasnita Ku Samsu \& Mohd. Mahadee Ismail

To Link this Article: http://dx.doi.org/10.6007/IJARBSS/v11-i8/10790 DOI:10.6007/IJARBSS/v11-i8/10790

Received: 27 June 2021, Revised: 30 July 2021, Accepted: 05 August 2021

Published Online: 20 August 2021

In-Text Citation: (Bing et al., 2021)

To Cite this Article: Bing, S., Fee, L. Y., Samsu, K. H. K., \& Ismail, M. M. (2021). The Voices of Malay and Chinese University Students in Klang Valley Towards National Identity Formation in Malaysia. International Journal of Academic Research in Business and Social Sciences, 11(8), 964-980.

\section{Copyright: @ 2021 The Author(s)}

Published by Human Resource Management Academic Research Society (www.hrmars.com)

This article is published under the Creative Commons Attribution (CC BY 4.0) license. Anyone may reproduce, distribute, translate and create derivative works of this article (for both commercial and non-commercial purposes), subject to full attribution to the original publication and authors. The full terms of this license may be seen at: http://creativecommons.org/licences/by/4.0/legalcode

Vol. 11, No. 8, 2021, Pg. 964 - 980

Full Terms \& Conditions of access and use can be found at http://hrmars.com/index.php/pages/detail/publication-ethics 




\title{
The Voices of Malay and Chinese University Students in Klang Valley Towards National Identity Formation in Malaysia
}

\author{
Siaw Bing ${ }^{2}$, Lee Yok Fee ${ }^{1,2}$, Ku Hasnita Ku Samsu² \& Mohd. \\ Mahadee Ismail ${ }^{2}$ \\ ${ }^{1}$ Institute of Social Science Studies (IPSAS), Putra Infoport, Universiti Putra Malaysia, 43400 \\ UPM, Serdang, Selangor, Malaysia, ${ }^{2}$ Faculty of Human Ecology, Universiti Putra Malaysia, \\ 43400 UPM, Serdang, Selangor, Malaysia. \\ Email: leeyokfee@upm.edu.my
}

\begin{abstract}
Malaysia has a unique society with its ethnic diversity and cultural uniqueness. Diversity has become a challenge to the formation of national identity because each ethnic group wants to maintain its own ethnic identity. Malaysia has been striving to form a national identity by strengthening the bonding and harmony among the people, but it has not achieved a satisfying state until now. Therefore, a study was conducted with the objectives to understand the voices of the Malay and Chinese university students in Klang Valley towards the challenges in the formation of national identity and their suggestions to improve the formation. The data were collected in Malaysian public and private universities by using a sequential mixedmethod approach. Focus Group Discussions (FGDs) were first conducted to explore students' views and then a survey was carried out by distributing questionnaires to collect data from a larger population in the selected universities. The outcomes of FGDs and survey found that people's ideas were not considered in the implementation of the policy by the government, the attitudes of the people like racism and intolerant to other ethnic groups, and unfairness in policy and weak leadership are the challenges in the formation of national identity. To overcome the challenges, this study found that government, people, parents, and university play significant roles in forming national identity. This study identified that it is important to understand grassroots voices in the implementation of national identity formation projects in a country.
\end{abstract}

Keywords: National Identity, Ethnic Identity, National Identity Formation, University Students.

\section{Introduction}

Forming a national identity is a common phenomenon around the world. In any country's national building project, national identity formation is an important agenda to unite the people and raise the spirit of patriotism for the country, especial for a country with multiethnic like Malaysia. Malaysia is notable as a unique country because of its diversity of ethnicities, religions, and cultures. The population consists of the main ethnic, namely the 
Malays, Chinese, and Indians. Every ethnic group has been practicing its own beliefs, cultures, and religions respectively since the pre-colonial period. The diversity can be seen as an advantage for Malaysia especially in the development of tourism. However, the diversity of ethnic identities has become a challenge to the formation of national identity because all ethnic groups want to maintain their own ethnic identity so that it will not be eroded and disappear.

Since independence, especially after the 13 May 1969 incident, Malaysia has been striving to form a national identity among the citizen by strengthening the bonds of unity and harmony among the ethnic groups. And yet, there have several issues of misunderstanding among the community especially between the Malays and Chinese (Noor, 2010). This is because each community still prioritizes their ethnic identity in terms of religion, language, and culture rather than national identity (Iszahanid, 2019; Noor, 2018; Omar, 2017). This attitude has preceded the priority for the formation of national identity. The situation has caused social issues like questioning the status of national-type Chinese and Tamil schools which use the mother tongues as a medium for teaching and learning, and also how to prioritize the use of Malay language as the national language. The existence of the national-type schools was seen as a key factor that created an ethnic boundary and barricades the social interaction among the multi-ethnic students (Yahaya, 2019; Jamaluddin, 2011). Students of the schools were said to emphasize more on their mother tongues rather than national language (Hassan, 2020). As a contestation to the issue, the upholding Malay language was raised to strengthen citizens' national identity to ensure that national language would not be marginalized (Ahmad, 2020; Halid, 2019; Sukiman, 2019; Awang, 2019; Iszahanid, 2017).

To achieve the goal of forming a national identity, the Malaysian government has implemented numerous policies and programs to unite all ethnic groups. For example, the New Economic Policy (NEP) emphasized social integration and equitable distribution of income among ethnic groups for national unity. Besides that, national ideology, Rukun Negara was introduced to strengthen inter-ethnic relations and ensure the stability of the country. Other than that, former prime minister (1981-2003 \& 2018-2020), Tun Dr. Mahathir Mohamad introduced Malaysian Nation, or Bangsa Malaysia the idea of nation-building when he attended a conference at Malaysian Business Council on 29 February 1991 (Embong, 2006). In addition, another formal prime minister (2009- 2018), Dato' Sri Haji Mohd Najib bin Tun Haji Abdul Razak introduced the idea of "1Malaysia" to promote national unity.

The government has made various efforts in the formation of national identity and to forge national unity that keeps the people together. However, until now the achievement is considered unsatisfactory. This could be due to the top-down approach employed by the authority, in which the main concern was based on the government's idea of what does the government wants in the development of the country. Meanwhile, they may not understand the situation and the real problems faced by the grassroots. Hence, the implemented policies and programs might not have met the desires of the people.

As the youth generation is the future leaders of our country, many studies on the youth have been conducted to ensure the country's sustainable prosperity and sovereignty. In the studies of national identity, Liu, Lawrence, Ward, and Abraham (2002) have researched 395 undergraduate students in the National University of Singapore dan University Malaya. The study found that Malaysians have a stronger ethnic identity rather than national identity, especially among the Malays. In addition, Othman et al (2012) have also researched 800 students from public universities to examine their level of national identity. Based on their findings, only 54.6 percent of students were at a high level. Besides that, their research 
showed that the score of national identity among the Chinese is lower than Malays and Indians. In general, previous studies suggested that political and educational aspects were important mechanisms in the formation of national identity (Chew, 2013; Jamil \& Raman, 2012; Singh \& Mukherjee, 1993; Bacchus, 1989). Despite that, the insight and expectations of the grassroots especially among the younger generation have not been emphasized in the previous study. The insight of the young generation particularly the university students should be taken into account because they are an important asset and future leaders of the county. Hence, this paper aims to identify the main challenges in the formation of national identity based on the voices of the Malay and Chinese university students in Klang Valley and also their suggestions towards the formation of national identity. This study focuses on the Malay and Chinese students but excludes the Indian students because most of the issues of misunderstanding that related to national unity happened between the two ethnic groups (Noor, 2010).

\section{Literature Review}

Generally, national identity has been related to different dimensions by different scholars. For example, Anderson (1983) explained that national identity refers to an imagination of collective belonging. The community members imagine themselves as a part of the community even though they have not known, interacted, or met one another. Smith (1991) also clarified that national identity refers to the sense of belonging of a community within a political boundary. Besides that, national identity is also subjective and complex where the people have a sense of belonging by sharing the same characteristics. For example, like history, language, descent, and culture (Tartakovsky, 2018; Simpson, 2016; Barret, 2005).

The formation of national identity is a fundamental issue in a country. National identity is an important element that binds a community together regardless of their ethnic, religious, or descent background. The formation of national identity shows the uniformity and understanding in society leading to national unity in a diverse society. Hence, every citizen should have a strong national identity to bond with each other together.

There are different factors emphasized when discussing the formation of national identity in the previous studies. The factors are politics, education, history, and language. Tsai (2007) described that the political factor plays the most important role in forming national identity. He explained that the ideology of the country's leader and changes in the political system such as from autocratic to democratic have reshaped Taiwan's national identity. While Mader et al (2018) also clarified that political factors are important because American identity is often related to political ideology. Their study found that the people who classified themselves with left or right parties have a high level of national identity towards their country. Thus, they concluded that national identity is related to political ideology.

Meanwhile, some scholars highlighted education as an important factor for the formation of national identity in their previous studies. Lowe (1999) concluded that formal and informal education are the main mechanisms in developing a country and fostering responsibility among the people. In addition, Lee (2003) suggested education is also a strong foundation for individuals' national identity, enables them to contribute to the well-being of life, and keeps a nation's success. While education is also one of the ways to create the loyalty of people to the country (Asari, Halikiopoulou \& Mock, 2008). According to Razak (2009), people will be educated with a sense of belonging and be proud to be Malaysian through certain methods, tools, and education procedures. Idris, Hassan, Ya'acaob, Gill, and Awal (2012) have conducted a study on 375 respondents to identify the relationship between education and 
national identity through questionnaires. The findings show that education contributes significantly to the formation of national identity.

In education, transmitting national history knowledge is also one of the important factors in national identity formation, especially among the younger generation. It helps to create a greater appreciation towards one's own country and also ensure sustainability. According to Asari, Halikiopoulou, and Mock (2008) and Korostelina (2013), history plays an important role in forming and strengthening national identity. Similarly, Matsuda (2004) said that individuals explore and determine their national identity as well as national identity through the historical background.

However, in Malaysia's context, the knowledge of the younger generation about the history of their homeland is very low and lacks appreciation (Jaafar, 2018). Tohar, Ani, and Razali (2019) and Razak (2009)'s studies further highlighted a great need to form the national identity among the younger generation through the education of history subjects. Therefore, educating the citizen about the national history is an important key in forming national identity.

Besides that, in the discussion of language as a factor, studies conducted by Poole (1994) and Ben-Ghiat (1997) have concluded that language plays a significant role in forming national identity. Jalaluddin (2010) illustrated that language symbolizes the identity of a country and is one of the characteristics of national identity to be proud of. Conversely, Davies and Dubinsky (2018) described that language is not only a national symbol but a common communication tool for governments and society.

Similarly, Rashid (2004) explained that language is fundamental in forming national identity and is important in instilling a sense of belonging among the citizens. It is a symbol of a country (Jaafar, 2008) and an important tool in ensuring unity among different ethnicities (Jalaluddin, 2010). However, the findings from Nahar and Rahman (2018) on primary school students and Tohar, Halim, and Samsu (2017) on university students showed that the proficiency level of national language among the students is low.

In short, past researches pointed out the factors such as history, education and language are important factors that overwhelmed the process of national identity by using a top-down approach. Nevertheless, the views from the grassroots should be taking into account especially among the youths. Thus, this study attempted to address this gap by engaging the bottom-up approach to identify Malay and Chinese students' insights towards national identity.

\section{Methodology}

This study was conducted using a mixed-method approach which was a combination of qualitative and quantitative approaches to identify Malay and Chinese students' insight in Klang Valley towards the formation of national identity. The mixed-method approach was chosen because it helped the researcher understand a phenomenon and create a comprehensive understanding of research questions compared to a single approach (Gay, Mills \& Airasian, 2009; Creswell \& Clark, 2007). The mixed-method approach is considered a practical approach to answer research questions because it helps the researcher understand a phenomenon deeply (Edmonds \& Kennedy, 2017). Therefore, the mixed-method approach was conducted to achieve the aims of this study.

In this study, a qualitative method Focus Group Discussion (FGD) was first conducted to explore the university students' insight regarding the research questions and then the findings 
were used to form a questionnaire. After that, a quantitative method which is a survey was conducted to obtain data from university students.

The participants of this study were students from public universities and private universities, who aged 18 to 25 years in Klang Valley. In the first stage, five Malay and five Chinese students were involved in two sessions of FGD. While in the second stage, in conducting a survey, researchers have determined the sample size as 384 respondents according to Krejcie and Morgan's (1970) table for determining sample size. However, extra samples were collected to reduce sample errors during the data collection, thus this study involved 400 university students as respondents.

This research employed a sequential mixed method. FGDs had been conducted first and then a survey was implemented later. The findings obtained from FGDs were analyzed descriptively through the process of coding and categorizing to form themes. After that, the qualitative findings then were used to develop a survey instrument. The items used to gauge the respondents' agreement in the instrument were measured using Likert Scales with a range from 1 to 6 . The means of the respondents' agreement on the items were computed using Statistical Package for the Social Science (SPSS).

\section{Results and Discussion}

In this section, data collected from FGDs will be presented first and followed by survey findings.

\section{Challenges in the formation of national identity}

\section{Results of Focus Group Discussions}

Data collected from the Malay and Chinese informants in FGDs revealed that Malaysian citizens and the government are still overwhelmed with the issues related to national identity formation. Both Malay and Chinese informants expressed that even though Malaysia has achieved its independence for more than 60 years, the racial issue remains a problem in Malaysia. Malay informant, M3 explained that until now the racial issue still could not be solved is due to the attitudes of intolerant and also prejudice towards other ethnic groups. Similarly, several Chinese informants expressed the same idea regarding the racial issue. Informant C5 said, "...there is a racist issue that we could not solve. This is a challenge in our country since long time ago until now" His thought was agreed by informant C4 who added that racial issues are being raised from time to time, therefore it is difficult to unite all people. Besides that, the issue of overemphasis on their own ethnic identity was also discussed by the informants. Firstly, both groups of informants stated that all ethnic groups want to maintain their own ethnic identity and struggle for their ethnic interests rather than national identity. Informant M5 stated that people from different ethnic groups want to maintain their own ethnic identity. Meanwhile, informant $\mathrm{C} 5$ also said that "One more thing is we are selfish, we just want to maintain our own identity." His view was agreed upon and elaborated further by informant C1, who said, "I think we have a higher racial identity compared to national identity. Because we would say he is Malays, he is Indians but we wouldn't say we are Malaysians." Secondly, Malaysian people do not want to make a change and are irresponsible towards the country. Informant $\mathrm{M} 2$ explained that the government has been working hard in forging unity but the problem is people do not want to make a change and cooperate with the government to achieve the goal of national identity. He gave an example of the idea of 1Malaysia, the implementation of it could be failed if people do not want to cooperate and work together. For informants $\mathrm{C} 1$ and $\mathrm{C} 5$, they described that the attitude of irresponsible can be observed 
when people identify and categorize themselves and others according to ethnic groups but do not see others as part of the nation. "When a critical issue or ethnic issue happened, we will classify ourselves as Malays or Chinese but not as Malaysian." Informant C1 said.

Finally, the last attitude discussed by both Malay and Chinese informants is a prejudice that happened in society. Based on informant M5, prejudice can be seen through the community's lifestyle when the people only want to get along with their ethnic group. That is the most worrying situation for him because it will cause conflicts and disunity to happen in society. His explanation was agreed by informant $\mathrm{M} 2$, as she said: "The main challenge in forming national identity is prejudice. Although we have achieved independence for a long time, I think it still repeats... Prejudice among Malaysians is high, negative is higher than positive." Similarly, a Chinese informant, C1 stated that prejudice among people is because of the classification of ethnicity since childhood. Her view was further elaborated by informant C4 said, "...for example, like group assignment, we have a prejudice against the Malays, they are lazy, we don't want to do with them and tend to do with Chinese..." Hence, both groups of informants defined that this attitude is the problem in shaping national identity.

Nevertheless, there are also different views among Malay and Chinese informants as they have different emphases about the challenges in terms of governance and humanity. For Malay informants, several discussed the implementation of the policy by the government has neglected the people and caused a loss of trust in the government. Informant M4 indicated that people do not have a strong national identity due to the implementation of policy and laws is only based on the government's idea. He clarified that government is not sensitive to the people's issues and causes failure in forming a national identity.

Besides that, the use of different languages as a medium of teaching and learning in education was also discussed as a challenge in forming a national identity. Informant M5 stated that the current Malaysian education system is one of the main factors that has separated the people. He explained that different ethnic groups do not have the opportunity to communicate and get along together with other ethnic groups since childhood because of studying in different schools that using different mediums.

Other than that, the Malay informants also expressed no understanding between the government and the people. Government has its ideas in implementing the policies, while people hope that the government could have listened to their voices so that the policies could meet their wants and needs. As informant M4 expressed, government and people have different ideas and hopes, so this has become a challenge in forming national identity.

On the other hand, Chinese informants highlighted different aspects concerning the government, which are poor leadership and injustices. Informant C1 stated that the government has no ability to lead and unite the people in this country. She said, "Government always said that they have a vision and plan to achieve unity. But when there are critical problems happened, they are unable to show their leadership..." In addition, she also emphasized the weakness of the political system and leadership that caused the people to not be loyal to the country. Her explanation was further elaborated by informant C4 who added that "we refuse to recognize and respect our leaders because of the weakness of the political system; this is also one of the challenges."

When discussed the injustice, Chinese informants have mentioned several aspects. Firstly, there are injustices in the implementation of the laws that favor certain ethnic groups. For example, it is only beneficial to one ethnic group and overlooks other ethnics' interests. Informant C1 said, "There are many policies and laws that seem to be more beneficial to a 
certain ethnic group, only for that ethnic group but not for others." Similarly, informant C2 shared her view, her description is as below:

"I think we can see that not all ethnic groups have equal rights although it is said that there are democracy and equality... the Malays, who lead the country so they certainly have more power than others."

Secondly, the special position of the Malays and native group compared to the Chinese. As informant C2 stated that only the Malays have a special position. Her views were agreed by informant C3 and she felt that there is no justice among the citizens due to this privilege and special position. Thirdly there is an unfair quota system in the country. Based on Chinese informants' view, there is no equality when an ethnic-based quota system is implemented in public university enrollment and government job applications. Informant C1 said, "For example like public universities admission, we can see that most are the Malays. Maybe some of the people have good results but weren't ever been given an opportunity to enter university. "While informant C2 expressed the inequality in a government job application. She said, "The quota system seems already be fixed that Malays have how many percentage... Even though 1Malaysia, we can see that Malays have been given more opportunity..."

Meanwhile, Chinese informants also mentioned that the category of ethnic in the forms has caused them to classify themselves according to their ethnic groups but not see themselves as Malaysian. Informant C4 said, "...we do not have the sense of Malaysian because of the category of ethnic." His view was agreed upon and further elaborated by informant $\mathrm{C} 1$, who said, "...no matter what form, why must we have the category of Malay, Chinese, Indian and other ethnic? Why not only Malaysian and non-Malaysian?" Therefore, she felt that the category of ethnic has caused a lack of sensation about national identity.

Next, different views among Malay and Chinese informants were also identified in the aspect of humanity. For the Malay informants, the awareness of respecting others in the society is low. Informant M1 and M3 explained that racial issue could be avoided and national unity can be maintained if the community have the awareness of respecting each other. Informant M3 said, "People should realize that we should respect other ethnic groups, no racism, no prejudice against other ethnic..." Hence, the attitudes, as well as the behavior of the people, are the challenges in the formation of national identity. Besides this, the Malay informants also clarified that the appreciation for the National Ideology, the Rukun Negara among the people is low. Informant M3 said that the people do have the knowledge and know what Rukun Negara is about but do not adhere to its principles. Consequently, various negative behaviors and situations occur because the appreciation of Rukun Negara is low. Furthermore, ethnic diversity has also been seen as a challenge in the formation of national identity. Informant M1 said, "For me, the challenge to form a national identity is ethnic diversity in our country." She explained that although ethnic diversity is the country's uniqueness, different ethnic groups only practice their own beliefs, religions, and cultures, they do not have a good understanding of others' religions and cultures. Thus, ethnic diversity is considered a challenge in forming a national identity among the people.

Meanwhile, the Chinese informants highlighted that the acceptance of different cultural practices among ethnic groups is one of the problems of humanity. Informant C5 said, "there is a problem of acceptance of different cultures, religions, lifestyles, and thoughts." Informant $\mathrm{C} 1$ has a similar view about the acceptance of cultural practices. She said, "sometimes we are not wearing too little, maybe pants above the knees, but they also criticize us... Maybe our religions are different, but why don't they respect us?" She shared her dressing experience in a hostel where she wore proper clothes but reprimanded by other ethnic groups. Hence, she 
felt that there is a problem of acceptance among ethnic groups. In the discussion, several Chinese informants highlighted that people do not have a common goal to move forwards to achieve unity. Informant C5 indicated, "...we do not have the same goal. We only focus on our career, family, and education." Thus, there is no sense of belonging and common goal among the people, and which has delayed the process of forming national identity.

Furthermore, parental teaching and parents' behavior were also discussed. Based on the descriptions of Chinese informants, the parents' teaching and behavior towards other ethnics impact the children's inter-ethnic interaction. For example, the parents who have stereotypes towards other ethnic groups will cause their children to become prejudice and not willing to interact with other ethnic groups. Informant $\mathrm{C} 1$ shared her view by giving an example, she said, "for example when a mother told her children not to be close with the Indians and Malays, because Indian is black and a bad person... Malays are lazy, not efficient in work." She felt that this might cause prejudice and discrimination from the young age of the children. Informant C4 also expressed a similar view and said that parents' teaching will affect their children's thoughts and behavior. If this situation continues, it would cause disunity and disharmony among the people and ruin the national identity formation among them.

In short, the findings from FGDs show that the Malays and Chinese informants shared similar views regarding the attitudes of the people like intolerant to other ethnic groups and strong tendency to maintain their own ethnic identity are the challenges in the formation of national identity. At the same time, there were also different views and aspects emphasized by both groups in terms of governance and humanity.

Results of Survey

Table 1.1 shows the mean values of the agreement of the respondents based on their perception of the challenges in the formation of national identity. The findings show that the respondents agreed to statement 19 the most with a mean $=4.72$. The respondents deem that the item "The implementation of the policy is only based on the idea of government but not the people." is the greatest challenge in the formation of national identity. Besides that, respondents also considered items in statement 8 "Racist issue among the people" (mean = 4.64) and statement 16 "The weakness of political system and leadership have made the people are not loyal to the country." (mean $=4.64$ ) as secondly or thirdly important challenges in national identity formation. Meanwhile, item no. 5 "Ethnic diversity is an obstacle to achieve unity." was considered as the least important challenge. The respondents also agreed on other challenges mentioned in Table 1.1 with a mean value of 4.14 to 4.59 . 
Table 1.1. Challenges in the formation of national identity $(n=400)$

\begin{tabular}{|c|c|c|}
\hline No. & Statement & Mean \\
\hline 1 & $\begin{array}{l}\text { People do not want to change and cooperate with the government to } \\
\text { achieve the goals of national identity. }\end{array}$ & 4.47 \\
\hline 2 & Every ethnic group wants to maintain its own ethnic identity. & 4.51 \\
\hline 3 & The negative attitude of the people like prejudice among the society. & 4.45 \\
\hline 4 & $\begin{array}{l}\text { Different languages as a medium of education have separated all ethnic } \\
\text { groups. }\end{array}$ & 4.14 \\
\hline 5 & Ethnic diversity is an obstacle to achieve unity. & 3.96 \\
\hline 6 & The awareness of respecting other ethnicities is low in society. & 4.29 \\
\hline 7 & $\begin{array}{l}\text { There is no understanding between government and people in } \\
\text { implementing policies. }\end{array}$ & 4.42 \\
\hline 8 & Racist issue among the people. & 4.64 \\
\hline 9 & Poor leaderships in uniting people. & 4.52 \\
\hline 10 & $\begin{array}{l}\text { Parents who have stereotype and discriminate against other ethnic } \\
\text { groups have caused their children to be prejudice from an early age. }\end{array}$ & 4.28 \\
\hline 11 & Unfair quota system in Malaysia. & 4.55 \\
\hline 12 & $\begin{array}{l}\text { The special position of the Malays and native group compared to } \\
\text { Chinese. }\end{array}$ & 4.55 \\
\hline 13 & $\begin{array}{l}\text { A problem in accepting different cultural practices among ethnic } \\
\text { groups. }\end{array}$ & 4.38 \\
\hline 14 & The category of ethnic in all forms has separated the people. & 4.18 \\
\hline 15 & There is no sense of belonging among the people. & 4.25 \\
\hline 16 & $\begin{array}{l}\text { The weakness of the political system and leadership have made the } \\
\text { people are not loyal to the country. }\end{array}$ & 4.64 \\
\hline 17 & Injustice in the implementation of laws. & 4.59 \\
\hline 18 & People do not have a common goal to move forwards to achieve unity. & 4.46 \\
\hline 19 & $\begin{array}{l}\text { The implementation of policy is only based on the idea of government } \\
\text { but not the people. }\end{array}$ & 4.72 \\
\hline 20 & Low appreciation of Rukun Negara among the people. & 4.53 \\
\hline
\end{tabular}

\section{Source: Fieldwork data 2017}

This finding is different from most of the previous studies regarding obstacles in national identity formation. According to Antal (2005), legal injustice is a major obstacle in a forming national identity. Based on his finding, the relations between people will be affected, and the feeling of pride in their country becomes less when the law favors one group. Besides that, past studies found that globalization reduces people's feelings towards national identity (Wang \& He, 2014; Woongjae, 2008), and ethnic diversity seen as a threat to national identity (A'zmi, Mustafar, Karim \& Suhaini, 2017; Embong, 2006; Jones, 1997). Compare to the previous studies, this study identified that according to the youth's perception, the implementation of policy that is only based on the idea of government but not the people is the main challenge in the formation of national identity.

Suggestions towards the formation of national identity 


\section{Results of Focus Groups Discussions}

Findings from the FGDs highlighted that government plays an important role in fostering a sense of belonging and forming national identity. The Malay and Chinese informants expressed a similar view that government should organize more community activities that involve all ethnic groups. Informant M2 explained that such activities provide an opportunity for all ethnic groups to get to know each other regarding cultures and festivals. Similarly, informant C3 also suggested the same idea because such activities help the multi-ethnic community to get along and live together.

Besides, the FGDs results also indicate that government should hold campaigns to create awareness and disseminate correct understanding of national identity. Informant M1 and C4 suggested a similar view that government should hold campaigns to create awareness and explain what national identity is among the people. They explained that people will have a clear picture of national identity and its importance through the campaign. Also, the government should provide education on national identity among the people from an early age. Informant M5 said, "Government needs to concern about the education system... should be more rational and critical about unity since they're a child and young." This idea was also shared by informant $\mathrm{C} 2$ and $\mathrm{C} 5$, they added that education can strengthen inter-ethnic relations and also ensure the national unity of a country.

Other than that, informants in FGDs also suggested that government should take into account the factor of ethnic diversity and restructure the education system. Informant M1 said that government should restructure and improve the education system to instill a sense of belonging among the ethnic groups. Similarly, informant C5 said that government should restructure the education system to ensure all students learn the mother tongues of all ethnic groups, i.e. Malay, Chinese and Tamil languages in school. On the issue of restructuring education, informants $\mathrm{C} 1$ and $\mathrm{C} 2$ had a different opinion, they emphasized the issue of the quota system. Both of them mentioned that the education system in Malaysia is unfair because not everyone has the same opportunity in education. Therefore, they suggested that the education system should not be based on ethnic quotas but be equal to all regardless of ethnicity.

Related to the language issue above, the informants suggested that a need to have a single education system to unite various ethnic groups. According to informant $M 1$, with the single education system, the current different vernacular or national-type schools are to be combined into one school to educate and foster national integration among people. The same opinion shared by informant $\mathrm{M} 2$ and indicated: "We have various ethnicities and religions, we respect each other. I think that not to abolish Chinese and Tamil primary schools... maybe combine all, give quota not only for our own ethnic..." Similarly, a Chinese informant C5 also suggested to have a single education system where a single school to teach all three types of language and all students study in it. With this, students are given the opportunity to interact and bond with different ethnicities from a young age, strengthening national unity and forming national identity in a long run.

In the FGDs, the Malay and Chinese informants also highlighted that government should be people-oriented to fulfill people's needs. Informant M4 indicated that government should prioritize the needs and hope of people so that the goal of national unity can be achieved. A Chinese informant C1 shared a similar suggestion, said, "Government should concern the people and listen to their voice and needs." She believed that if people's voices are listened to by the government, the goal of national identity can be achieved. 
In addition to the government's role, Malays and Chinese informants shared a similar view that the people also play an important role in forming national identity. Informant M1 and C1 suggested that people should not raise any racial issues so that people can live harmoniously together. As informant M3 said, "... as a citizen, we should avoid sensitive issues. If we could not help to achieve unity, at least we can avoid sensitivity issues of ethnic." Besides that, informants also thought that parents should show a positive attitude towards other ethnic groups in front of their children. This is because children adopt the parents' attitude towards other ethnicities. Informant M1 said, "Parents should not restrict children to play with the children of different ethnics... Parents should be open-minded and do not look down at others." Informant C4 expressed a similar view and said, "Parents play an important role in terms of family... Do not classify all Indians as bad people or Malays as lazy...because children learn from parents." Hence, people and parents play a role in the formation of national identity. However, in the FGDs, some of the Malay and Chinese informants' comments are different when they were asked to describe the role of government and people. When discussing the role of government, the Malay informants emphasized that the people should be more tolerant and understand the role of government. Informant M4 suggested that government and citizens should be tolerant of each other. His view was further elaborated by informant $\mathrm{M} 2$, who said "even if we do not agree about what government is proposing, but we should try to think about the future of our country and tolerate." For them, understanding is important to achieve national identity. However, the Malay informants also suggested that government should be a good example to people by showing a good relationship between ethnic groups. Informant M1 explained that a good relationship between the government with all ethnic groups is significant in strengthening people's confidence towards the country. The focus of the discussion on the role of the government of the Chinese informants was different. They were more concerned about the issue of equality. Informant C1 described that government should be fair in preserving every citizen's interest regardless of ethnicity because they have the right to be treated equally. While informant C4 suggested that the leaders of the country need to be fair and equitable in the implementation of social policies. As he said, "Policy needs to be fair for all citizens so that they can have the same opportunities in politics, social and economic." Besides that, the Chinese informants also suggested that government hold activities and programs to strengthen the people's sense of belonging. The activities provide an opportunity for people to interact and bond them together, at the same help to shape the national identity. As mentioned earlier, the category of ethnicity in the forms has caused the people to classify themselves according to their ethnic groups. So, the Chinese informants also suggested that the category of ethnic in all forms should be abolished.

Regarding the people's role, Malay informants explained that the people should be openminded and tolerant toward each other to form the national identity. Informant M2 said, "The people should keep a positive attitude. We should be open-minded, tolerant, and be united in fostering national identity." While informant M5 and M2 mentioned the national ideology, Rukun Negara. Both of them expressed a similar idea and said that the people should adhere to Rukun Negara's principles. They emphasized that the people must practice the principles that include courteous behaviors to maintain peace and harmony.

Meanwhile, the Chinese informants highlighted the responsibility of the people. Few suggested that Malaysians have to be responsible to the country to ensure harmony, peace, and unity. Informant C2 indicated that "the people should have a responsibility to the country. We as Malaysians must support Malaysia." While informant C3 described the people should 
perform their responsibility by not to criticize and not to be prejudice against other ethnic groups. She suggested that people can play a role when they see someone talks about bad things about other ethics, they must advise the person not to say so.

Other than that, informant C1 suggested that people should spread positive information about national identity on social media. She explained that she felt touched when she saw the video about Malaysia's uniqueness and harmony among ethnic groups. For her, this kind of information can improve cohesion among the ethnic groups. Besides, the university should provide a platform for students to express their views on unity issues and leadership problems. Informant C2 explained that nowadays university students have no freedom of speech and are worried about being punished by the government if they talk about politics. Hence, she said that there must have a platform for students to express their views and opinions.

In short, the findings from FGDs show that the Malay and Chinese informants have some similarities and differences in their suggestions on how to form a national identity. Overall, they have emphasized that the government and the people play an important role in fostering national identity. In addition, some of them further suggested that parents and university also play a significant role in strengthening national identity among people.

Results of Survey

Table 1.2 shows the values of the mean of the level of agreement based on respondents' perceptions on the twenty suggestions in forging a national identity. The finding shows that, with the reading of mean $=5.07$, the statement 15 i.e., "Country leaders should be peopleoriented in fulfilling the needs of people" is considered the most agreed suggestion in forging a national identity. Furthermore, statement 14, which is "Government should be fair in preserving the interest of every citizen regardless of ethnicity" is considered the second important suggestion with the reading of mean $=5.01$ and followed by the statement 18 , "Country leaders should be fair and equitable in the implementation of policy" with mean = 5.00. Besides that, the other suggestions stated in Table 1.2 were also agreed by the respondents with mean values between 4.20 to 4.98 respectively. 
Table 1.2. Suggestion in forging national identity $(n=400)$

\begin{tabular}{|c|c|c|}
\hline No. & Statement & Mean \\
\hline 1 & $\begin{array}{l}\text { Toleration between government and people to reach a common } \\
\text { understanding. }\end{array}$ & 4.88 \\
\hline 2 & The people should be open-minded and tolerant to one another. & 4.97 \\
\hline 3 & The people should avoid sensitive ethnic issues. & 4.82 \\
\hline 4 & $\begin{array}{l}\text { Government should take into account the factors of ethnic diversity } \\
\text { and restructure the education system. }\end{array}$ & 4.71 \\
\hline 5 & $\begin{array}{l}\text { Parents should show a positive attitude towards other ethnic groups } \\
\text { in front of their children. }\end{array}$ & 4.95 \\
\hline 6 & $\begin{array}{l}\text { Government should be a good example to people by showing a good } \\
\text { relationship with all ethnic groups. }\end{array}$ & 4.98 \\
\hline 7 & The people should appreciate Rukun Negara. & 4.68 \\
\hline 8 & $\begin{array}{l}\text { The single education system for the vision of uniting various ethnic } \\
\text { groups. }\end{array}$ & 4.20 \\
\hline 9 & The people have to be responsible for the country. & 4.90 \\
\hline 10 & $\begin{array}{l}\text { The people should spread positive information about national identity } \\
\text { on social media. }\end{array}$ & 4.87 \\
\hline 11 & $\begin{array}{l}\text { Government should provide education on national identity from an } \\
\text { early age. }\end{array}$ & 4.79 \\
\hline 12 & $\begin{array}{l}\text { The people should have a positive attitude such as not to criticize and } \\
\text { be prejudice towards other ethnic groups. }\end{array}$ & 4.95 \\
\hline 13 & $\begin{array}{l}\text { University should provide a platform for students to express their } \\
\text { opinion. }\end{array}$ & 4.86 \\
\hline 14 & $\begin{array}{l}\text { Government should be fair in preserving the interest of every citizen } \\
\text { regardless of ethnicity. }\end{array}$ & 5.01 \\
\hline 15 & $\begin{array}{l}\text { Country leaders should be people-oriented in fulfilling the needs of the } \\
\text { people. }\end{array}$ & 5.07 \\
\hline 16 & Government should hold campaigns regarding national identity. & 4.65 \\
\hline 17 & Abolished the category of ethnic in all forms. & 4.59 \\
\hline 18 & $\begin{array}{l}\text { Country leaders should be fair and equitable in the implementation of } \\
\text { policy. }\end{array}$ & 5.00 \\
\hline 19 & Strengthen the sense of belonging among the people. & 4.89 \\
\hline 20 & $\begin{array}{l}\text { Government should organize community activities that involve all } \\
\text { ethnic groups. }\end{array}$ & 4.79 \\
\hline
\end{tabular}

Source: Fieldwork data 2017

In short, the findings show that government plays an important role in the formation of national identity. The respondents demonstrated their emphasis that the government should concern more on the people's needs, voices and hope. According to Jalaluddin (2010) and Yahaya (2019), the monoethnic education system and vernacular school are the main factors emphasized by the people compared to the formation process of national identity. Therefore, a single education system has been suggested to ensure interaction and to build bonding among different ethnic groups (Jalaluddin, 2010). However, this study discovers that people's needs should be listened to, prioritized, and concerned by the country leaders is the most important matter in forming national identity. The respondents suggested that the leaders need to be sensitive to the issues faced by the people so that various measures can be taken 
to ensure harmony among people. With these, the goal to form a shared national identity among the people could be achieved in the future.

\section{Conclusion}

As discussed in the early part of writing, some scholars have examined the efforts of the country in forming national identity through a top-down approach. Meanwhile, this paper intends to identify the problems by using a bottom-up approach. The FGDs and survey results show that the Malay and Chinese students deemed the implementation of policy and the attitude of government do give an important impact on the formation of national identity. Both groups of students also highlighted that the attitude and behavior of the people, such as intolerance to other ethnic groups and fear of losing their cultural identity are the reasons why the formation of national identity is difficult to achieve. To overcome these problems, they mentioned that different parties have different roles to play. For example, the government to consider people's opinions and needs in implementing policy and the people's attitude in promoting national identity in their everyday life rather than putting their own ethnic identity as a priority. Also, parents and universities were considered to play significant roles in shaping people's national identity. Therefore, this research's findings provide a different set of knowledge derived from the social agencies' point of view on the formation of national identity. This knowledge is important for policymakers, governmental organizations in the future policy and programs making to strengthen the country's national identity.

\section{References}

A'zmi, A. A., Mustafar, F. W., Karim, A. K. A., \& Suhaini, N. (2017). Realiti kepelbagaian kaum ke arah perpaduan nasional pasca merdeka. Jurnal Sains Sosial, 2, 1-24

Ahmad, S. N. (2020). Sekolah vernakular punca Bahasa Melayu terpinggir. Berita Harian Online. Retrieved from https://origin.bharian.com.my

Anderson, B. (1983). Imagined communities: Reflections on the origin and spread of nationalism. London: Verso.

Antal, O. (2005). Hungarian national identity: old and new challenges, International Journal of Sociology, 35(4), 28-48.

Asari, E. M., Halikiopoulou, D., \& Mock, S. (2008). British national identity and the dilemmas of multiculturalism, nationalism, and ethnic politics. Nationalism and Ethnic Politics, 14(1), 1-28.

Awang, S. F. (2019). Usaha martabatkan Bahasa Melayu medium ikatan perpaduan. Sinar Harian. Retrieved from https://www.sinarharian.com.my

Bacchus, M. K. (1989). The role of education in achieving equity, cultural diversity, and national unity in multi-ethnic societies. Singapore Journal of Education, 10(2), 1-10.

Barrett, M. (2005). National identities in children and young people. In S. Ding \& K. Littleton (Eds.), Children's personal and social development (pp. 181-220). Milton Keynes: Blackwell.

Ben-Ghiat, R. (1997). Language and the construction of national identity in fascist Italy. The European Legacy, 2(3), 438-443.

Chew, F. P. (2013). Cerpen dan perpaduan nasional. Kuala Lumpur: Penerbit Universiti Malaya.

Creswell, J. W., \& Clark, V. L. P. (2007). Designing and conducting mixed methods research. London: SAGE. 
Davies, W., \& Dubinsky, S. (2018). Language and national identity. In Language conflict and Language Rights: Ethnolinguistic perspectives on human conflict (pp.99-131). Cambridge: Cambridge University Press.

Edmonds, W. A., \& Kennedy, T. D. (2017). An applied guide to research designs: Quantitative, qualitative, and mixed methods. Second edition. Los Angeles: SAGE.

Embong, A. R. (2006). Negara-bangsa: Proses dan Perbahasan (Edisi Kedua). Bangi: Penerbit Universiti Kebangsaan Malaysia.

Gay, L. R., Mills, G. E., \& Airasian, P. (2009). Educational research: Competencies for analysis and applications. Columbus: Pearson Merill Prentice Hall.

Halid, A. (2019). Memartabat bahasa kebangsaan, memperkukuh jati diri. Astro Awani. Retrieved from https://www.astroawani.com

Hassan, M. R. (2020, September 06). Antara amalan dan politik bahasa. Sinar Harian. Retrieved from https://www.sinarharian.com.my

Idris, F., Hassan, Z., Ya'acob, A., Gill, S. K., \& Awal, N. A. M. (2012). The role of education in shaping youth's national identity. Procedia Social and Behavioral Sciences, 59, 443-450.

Iszahanid, H. (2019). Masyarakat dahulukan agenda etnik bukan budaya kebangsaan. Berita Harian Online. Retrieved from https://www.bharian.com.my

Iszahanid. H. (2017). Bahasa Melayu tentukan identiti bangsa Malaysia. Berita Harian Online. Retrieved from https://www.bharian.com.my

Jaafar, J. (2008). Cabaran dan proses pemantapan Bahasa Melayu. Jurnal Pengajian Melayu, $19,68-90$.

Jaafar, N. (2018). Hayati sejarah bentuk generasi muda menerusi sejarah. Berita Harian Online. Retrieved from https://www.bharian.com.my

Jalaluddin, N. H. (2010). Bahasa Melayu dan jati diri dalam konteks Satu Malaysia: Satu kupasan linguistik. Jurnal Bahasa, 10(1), 1-16.

Jamaluddin, M. K. A. M. (2011). Sistem pendidikan di Malaysia: dasar, cabaran dan pelaksanaan ke arah perpaduan nasional. Sosiohumanika, 4(1), 33-48.

Jamil, H., \& Raman, S. R. (2012). Malaysian educational policy for national integration: Contested terrain of multiple aspirations in a multicultural nation. Journal of Language and Culture, 3(1), 20-31.

Jones, F. L. (1997). Ethnic diversity and national identity. ANZJS, 33(3), 285- 305

Korostelina, K. V. (2013). History education in the formation of social identity. New York: Palgrave MacMillan.

Krejcie, R. V., \& Morgan, D. W. (1970). Determining sample size for research activities. Educational and Psychological Measurement, 30, 607-610.

Lee, B. J. (2003). Education and national identity. Policy Futures in Education, 1(2), 332-341.

Liu, J. H., Lawrence, B., Ward, C., \& Abraham, S. (2002). Social representations of history in Malaysia and Singapore: On the relationship between national and ethnic identity. Asian Journal of Social Psychology, 5, 3-20.

Lowe, R. (1999). Education and national identity. Journal of the History of Education Society, 28(3), 231-233.

Mader, M., Scotto, T. J., Reifler, J., Gries, P. H., Isernia, P., \& Schoen, H. (2018). How political are national identities? A comparison of the United States, the United Kingdom, and Germany in the 2010s. Research and Politics, 1-9.

Matsuda, T. (2004). American studies: History. In International Encyclopedia of the Social \& Behavioral Sciences (pp. 1-11). Amsterdam: Elsevier. 
Nahar, N., \& Rahman, F. A. (2018). Tahap penguasaan kemahiran bertutur bahasa Melayu dalam kalangan murid bukan penutur natif. Jurnal Pendidikan Bahasa Melayu, 8(1), 7483.

Noor, M. M. (2010). Hubungan Melayu dan Cina di Malaysia masa kini: Buta dengan perubahan realiti sosial negara. Jurnal Demokrasi,9(2), 185-207.

Noor, M. M. (2018, Disember 18). Perlembagaan Persekutuan satukan bangsa. Berita Harian Online. Retrieved from https://www.bharian.com.my

Omar, A. H. (2017). Melestarikan adat perpatih dalam Gagasan Satu Malaysia. Jurnal Peradaban, 4, 67-91.

Othman, M. Y., Dakir, J., Samian, A. L., Hasim, M. S., Awal, N. A. M., Yahya, S. A., \& Bakar, M. A. (2012). Jati diri kebangsaan dalam kalangan pelajar institusi pengajian tinggi. Jurnal Hadhari Special Edition, 67-78.

Poole, R. (1994). Nationalism, ethnicity and identity. Journal of Area Studies, (4), 30-42.

Rashid, A. R. A. (2004). Patriotisme: Agenda pembinaan bangsa. Kuala Lumpur: Utusan Publications \& Distributors.

Razak, M. R. A. (2009). Pembinaan negara bangsa Malaysia: Peranan pendidikan sejarah dan Dasar Pendidikan Kebangsaan. JEBAT, 36, 90-106.

Simpson, A. (2016). Chinese language and national identity. In The Routledge Encyclopedia of the Chinese Language (pp. 90-103). New York: Routledge

Singh, J. S., \& Mukherjee, H. (1993). Education and national integration in Malaysia: Stocktaking thirty years after independence. International Journal of Educational Development, 13(2), 89-102.

Smith, A. D. (1991). National identity. London: Penguin.

Sukiman, N. H. A. (2019, Mac 03). Bahasa Melayu bahasa rakyat Malaysia. Sinar Harian. Retrieved from https://www.sinarharian.com.my

Tartakovsky, E. (2018). National identity. In Encyclopaedia of Adolescence (2 ${ }^{\text {nd }}$ ed., pp. 24852499). Cham: Springer.

Tohar, S. N. A. M., Halim, A. A., \& Samsu, K. H. K (2017). Pengukuran tahap pemartabatan bahasa kebangsaan dalam mahasiswa institusi pengajian tinggi. GEMA Online Journal of Language Studies, 17(2), 105-122.

Tohar, S. N. A. M., Ani, F., \& Razali, A. (2019). Penerapan identiti nasional melalui sejarah: membina kelestarian insan dalam kalangan generasi muda. Journal of Techno Social, 11(1), 54-60.

Tsai, C. Y. (2007). National identity, ethnic identity and party identity in Taiwan. Maryland Series in Contemporary Asian Studies, 2007(1), 1-34.

Wang, Z. J., \& He, H. L. (2014). National identity in the era of globalization: crisis and reconstruction. Journal Social Sciences in China, 35, 139-154.

Woongjae, R. (2008). Problems of national identity in an era of globalization: Turkey's bid to join the European Union. Journal of International and Area Studies, 15(1), 37-45.

Yahaya, A. (2019). Sekolah satu aliran satukan kaum. Sinar Harian. Retrieved from https://www.sinarharian.com.my 